International Conference on Renewable Energies and Power Quality (ICREPQ'11)

Las Palmas de Gran Canaria (Spain), 13th to 15th April, 2011

\title{
Investigation and Evaluation of Multilevel H- NPC Converter for Electrically Driven Trains
}

\author{
G. Adamidis ${ }^{1}$, N. Alagialoglou ${ }^{1}$ G. Tsengenes ${ }^{1}$ \\ ${ }^{1}$ Department of Electrical Engineering and Computer Engineering \\ Democritus University of Thrace \\ University Campus Kimmeria, 67100 Xanthi (Greece) \\ E-mail: adamidis@ee.duth.gr,nikos_ala@msn.com, gtseng@ee.duth.gr
}

\begin{abstract}
In this paper is analyzed and simulated on the computer the operation of a three level H-bridge converter as well as its parallel operations. Based on the simulation results the operating behavior between a) a three level H-bridge neutral point clamped converter, b) a three level H-bridge neutral point clamped converter with parallel elements and c) two three level H-bridge neutral point clamped converters parallel connected is being compared. From the simulation results is obvious that in the first two cases the ripples, the distortion in primary and secondary winding currents, and the power factor are quite satisfactory and almost identical to each other. In the third case as compared with the first two, we observe that current harmonics with higher amplitude appear in the primary winding of the transformer.
\end{abstract}

\section{Key words}

AC-DC Single-Phase converter, Modulation Strategy, Three level H-NPC topologies, Grid connected converter.

\section{Introduction}

AC-DC converters can be separated into converters which operate with low transition frequency and into converters with high transition frequency. The main disadvantage of these converters is the derivation of harmonics and reactive power [1], [2].

Harmonics have a negative impact on electrical power system operation, so particular attention to their generation and elimination is paid. Specifically, many international standards have introduced significant and strict limits on the harmonics which injected to the electrical power system [3].

A conventional method for harmonic elimination of the input currents is the usage of converters with high switching frequency. A further improvement is the usage of passive filters [4]. Over the last decade, active power filters have emerged for elimination of harmonics which are injected to the grid [5], [6].
A variant way to harmonic elimination is the power factor correction (PFC) [7]. With this method harmonics are eliminated and thus the power factor is improved, that is why they get this name. There are many applications where the power flow can be reversed during operation. Such examples are the driving systems in electric traction. Converters which operate in four quadrants with a high power factor are named active front end (AFE) converters, which can be classified into voltage source converters (VSC) and static var compensator (SVC) [8]. In electric traction the conventional circuit of a two level PWM converter is applied [9], [10]. In this case a unipolar PWM strategy of asymmetric samples is espoused for the converter.

Furthermore, in electric traction circuits three level PWM converters are applied. These converters have eight switching modules with eight anti-parallel diodes and four clamping diodes. The modules $\mathrm{S}_{1}, \mathrm{~S}_{2}, \mathrm{~S}_{3}$ and $\mathrm{S}_{6}$ switched on with $180^{\circ}$ phase shifting compared to $S_{3}, S_{4}$, $\mathrm{S}_{7}$ and $\mathrm{S}_{8}$ respectively. Therefore, there are only four independent modules which have sixteen switching states. If the modules $\mathrm{S}_{1}, \mathrm{~S}_{4}, \mathrm{~S}_{5}$ and $\mathrm{S}_{8}$ are selected as the four independent, the rest modules are the dependent modules. Since the modules $\mathrm{S}_{1}$ and $\mathrm{S}_{4}$, or $\mathrm{S}_{5}, \mathrm{~S}_{8}$ cannot switch on simultaneously there are seven redundant switching states. In conclusion, there are only nine valid switching states. Considering the cases for both positive and negative current flow, we end up with eighteen valid switching states for a three level PWM converter [11].

In recent years many research efforts are made to implement in the electric traction chain multilevel converters which are based on the cascaded connection of independently supplied single phase converters. These arrangements not only allow the connection at very high voltage levels with conventional semiconductor elements, but also the current which is generated in the secondary winding of the transformer has low harmonic content. In this case installing additional dc-dc converters allow the power exchange with the common output side [12]. 
In electric traction the transformers' primary winding is connected with a single phase overhead line of an $\mathrm{AC}$ electrical power system, and reduces the received voltage into a desirable level. The secondary winding of the transformer is used to feed the converters, which through DC link supply the electromotion system. Each of the secondary windings is connected to a four quadrants (4QC) converter. For the electrical power system investigation, the transformer is modeled based on the number of windings taking into account the ohmic resistance $R_{i}$, the inductance $L_{i}$ of each winding 1 and the mutual inductance Mij between the windings $i$ and $j$ of the transformer [13],[14]. In this paper different H-NPC topologies were investigated and compared, based on their performance, which is indicated by specific parameters.

\section{Analysis of H-bridge neutral point clamped converter}

In electric traction the H-bridge neutral point clamped $(\mathrm{H}-$ NPC) converter can be applied, as shown in fig.1.In this case, if the same semiconductor elements with those of a two level H-bridge converter are used, the amplitude of the input and output converter's voltage can be doubled while keeping constant both the quality of current harmonics and the amplitude of the current. The result is a more compact converter constituting of fewer parts and fewer secondary windings on the transformer for the same current value but with higher voltage. This is achieved by using more controlled semiconductor elements and more complex modulation strategy. Also in this case, if necessary, several converters can be connected in parallel to raise the total power capacity and eliminate current harmonics.

\section{$25 \mathrm{kV}$}

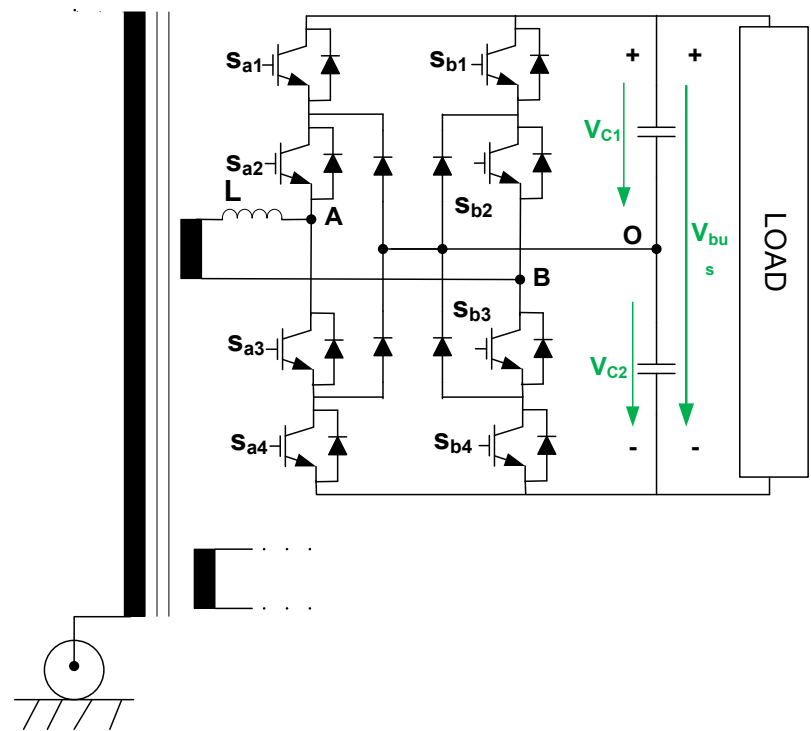

Fig. 1. Three level H-NPC converter.

The voltage in the secondary winding of the transformer is a five level voltage, whereas the line to neutral point voltage $\left(\mathrm{V}_{\mathrm{AO}}\right.$ or $\left.\mathrm{V}_{\mathrm{BO}}\right)$ is a three level voltage. In this converter, the line to line voltage waveform is bigger than the three level converter one. The transducer is found in the literature as three level, since the voltage waveform between line and DC bus neutral point determinates the level of the converter. Figure 2 shows the line to neutral point $(\mathrm{O})$ voltage waveform for each phase.

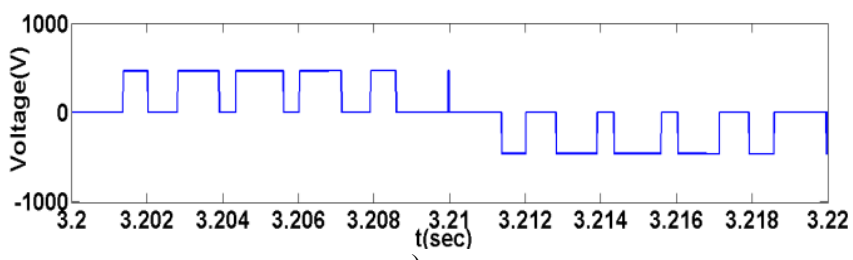

a)

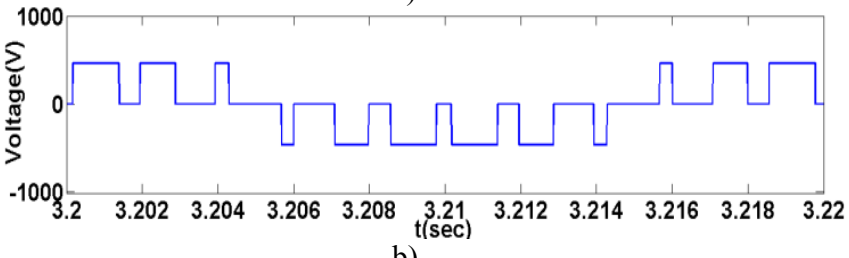

b)

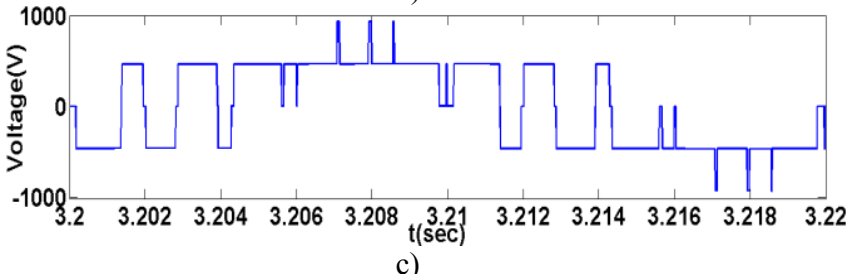

Fig. 2. a) Line to neutral voltage waveform for leg $A,\left(V_{A O}\right)$,

b) Line to neutral voltage waveform for leg $\mathrm{B},\left(\mathrm{V}_{\mathrm{BO}}\right)$,

c) Line to line voltage waveform $\left(\mathrm{V}_{\mathrm{AB}}\right)$.

The following paragraphs give a detailed description of the pulse width modulation strategy which was applied during the computer simulation for the above converter. The pulses for the elements of leg $A\left(\mathrm{~S}_{\mathrm{a} 1}, \mathrm{~S}_{\mathrm{a} 2}, \mathrm{~S}_{\mathrm{a} 3}\right.$ and $\left.\mathrm{S}_{\mathrm{a} 4}\right)$, are the result of comparing a sinusoidal signal $\left(\mathrm{U}_{\mathrm{st}}\right)$ with $0^{\circ}$ degree phase shifting and two triangular waveforms $\left(\mathrm{U}_{\text {tri }}\right)$ with $0^{\circ}$ and $180^{\circ}$ degree phase shifting respectively. The switching states for the leg A are shown in table I.

TABLe I-SWitching StATES FOR Leg A

\begin{tabular}{|c|c|c|c|c|}
\hline & $\begin{array}{c}\text { Ust }> \\
\text { Utri }\left(0^{\circ}\right) \\
\text { and } \\
\text { Ust }> \\
\text { Utri }\left(180^{\circ}\right)\end{array}$ & $\begin{array}{c}\text { Ust }> \\
\text { Utri }\left(0^{\circ}\right) \\
\text { and } \\
\text { Ust }< \\
\text { Utri }\left(180^{\circ}\right)\end{array}$ & $\begin{array}{c}\text { Ust }< \\
\text { Utri }\left(0^{\circ}\right) \\
\text { and } \\
\text { Ust }> \\
\text { Utri }\left(180^{\circ}\right)\end{array}$ & $\begin{array}{c}\text { Ust }< \\
\text { Utri }\left(0^{\circ}\right) \\
\text { and } \\
\text { Ust }< \\
\text { Utri }(180)\end{array}$ \\
\hline $\mathrm{S}_{\mathrm{a} 1}$ & On & Off & Off & Off \\
\hline $\mathrm{S}_{\mathrm{a} 2}$ & On & On & On & Off \\
\hline $\mathrm{S}_{\mathrm{a} 3}$ & Off & On & On & On \\
\hline $\mathrm{S}_{\mathrm{a} 4}$ & Off & Off & Off & On \\
\hline $\mathrm{V}_{\mathrm{AO}}$ & $+\mathrm{V}_{\text {Bus }}$ & 0 & 0 & $-\mathrm{V}_{\text {Bus }}$ \\
\hline
\end{tabular}

In correspondence, the pulses for the elements of leg $\mathrm{B}$ $\left(\mathrm{S}_{\mathrm{b} 1}, \mathrm{~S}_{\mathrm{b} 2}, \mathrm{~S}_{\mathrm{b} 3}\right.$ and $\left.\mathrm{S}_{\mathrm{b} 4}\right)$, are the result of the comparison between a sinusoidal signal $\left(\mathrm{U}_{\mathrm{st}}\right)$ with $90^{\circ}$ degree phase shifting and two triangular waveforms $\left(\mathrm{U}_{\text {tri }}\right)$ with $90^{\circ}$ and $270^{\circ}$ degree phase shifting respectively. The switching states for the leg B are shown in table II. 
TABLE II-SWITCHING STATES FOR LEG B

\begin{tabular}{|c|c|c|c|c|}
\hline & $\begin{array}{c}\text { Ust }> \\
\text { Utri }\left(90^{\circ}\right) \\
\kappa \alpha 1 \\
\text { Ust }> \\
\text { Utri }\left(270^{\circ}\right)\end{array}$ & $\begin{array}{c}\text { Ust }> \\
\text { Utri }\left(90^{\circ}\right) \\
\kappa \alpha \imath \\
\text { Ust }< \\
\text { Utri }\left(270^{\circ}\right)\end{array}$ & $\begin{array}{c}\text { Ust }< \\
\text { Utri }\left(90^{\circ}\right) \\
\kappa \alpha t \\
\text { Ust }> \\
\text { Utri }\left(270^{\circ}\right)\end{array}$ & 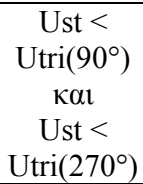 \\
\hline$S_{b 1}$ & On & Off & Off & Off \\
\hline $\mathrm{S}_{\mathrm{b} 2}$ & On & On & On & Off \\
\hline $\mathrm{S}_{\mathrm{b} 3}$ & Off & On & On & On \\
\hline $\mathrm{S}_{\mathrm{b} 4}$ & Off & Off & Off & On \\
\hline $\mathrm{V}_{\mathrm{BO}}$ & $-V_{\text {Bus }}$ & 0 & 0 & $+V_{\text {Bus }}$ \\
\hline
\end{tabular}

In practice, the single-phase sinusoidal grid voltage of $25 \mathrm{kV} \mathrm{AC}, 50 \mathrm{~Hz}$, transformed (degraded) to 510 Volts AC, $50 \mathrm{~Hz}$. Here we should mention that we have set the input inductor $20 \mathrm{mH}$, so the output voltage varying close to 900 Volts, which is the desirable value. The three level $\mathrm{H}$ bridge converter is connected at the output of the transformer. Figure 3 depicts the voltage of transformers' secondary winding, the sinusoidal control waveform and the triangular control waveforms for the leg A. Also fig. 3 depicts the sinusoidal control waveform, the triangular control waveforms for the leg $\mathrm{B}$, and the rectified $\mathrm{DC}$ voltage $\left(\mathrm{V}_{\text {bus }}\right)$ in the $\mathrm{DC}$ bus of the converter. The DC bus voltage is approximately 930 Volts.

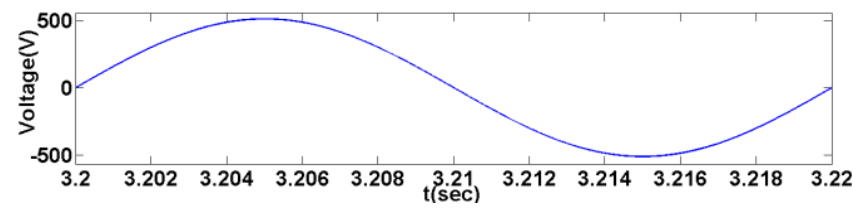

a)

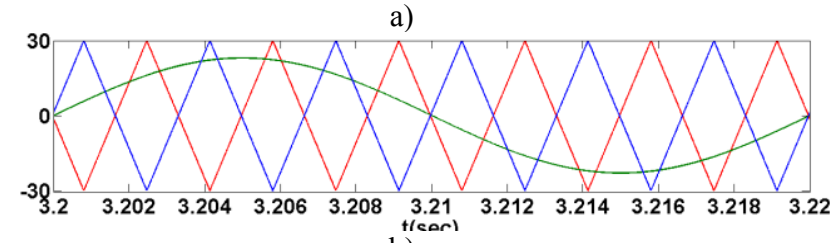

b)

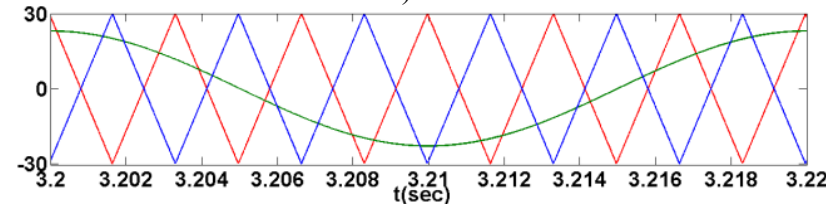

c)

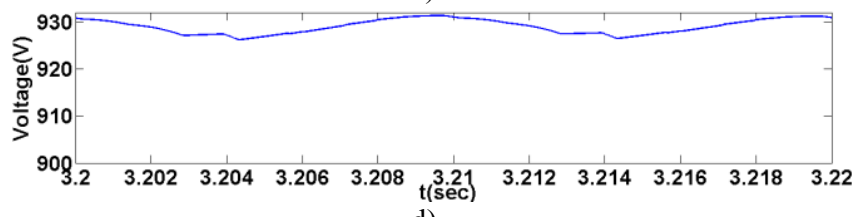

d)

Fig. 3. a) Voltage of transformer's secondary winding,

b) Sinusoidal and triangular control waveform for leg A,

c) Sinusoidal and triangular control waveform for leg B,

d) DC bus voltage.

As shown from fig. 3 the ripple of DC bus voltage is very small, approximately to $0.5 \%$ (from 925 to 930 volts). Figure 4 shows the current waveforms of the primary and the secondary winding of the transformer.

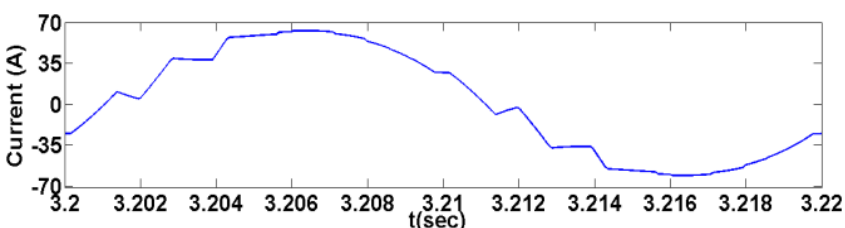

a)

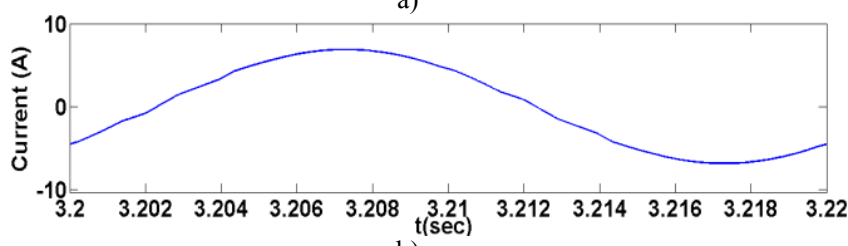

b)

Fig. 4. a) Converter's input currents,

b) Primary winding's current.

The total harmonic distortion of the input current of the converter is: $\mathrm{THD}_{\mathrm{i}} \approx 7.48 \%$

The total harmonic distortion of the current in the primary winding of the transformer is: $\mathrm{THD}_{\mathrm{iP}} \approx 1.38 \%$

The phase shifting between transformer's secondary winding current and secondary winding voltage is $18^{\circ}$ degree. Therefore the power factor is: $\cos \varphi \approx 0.95$

\section{Analysis of H-bridge neutral point clamped converter with parallel elements}

In this section will be analyzed the pulse width modulation strategy and then will be simulated the operation of the converter which is shown in fig. 5. The converter in fig. 5 is a variant of the H-NPC converter which was presented in the previous section.

In this case the control strategy is similar with the control strategy of the H-NPC in the previous section. We have again two control signals. The first control signal for the semiconductor elements $\mathrm{CG}_{11}, \mathrm{CG}_{12}, \mathrm{CG}_{21}, \mathrm{CG}_{22}, \mathrm{CG}_{31}$, $\mathrm{CG}_{32}, \mathrm{CG}_{41}, \mathrm{CG}_{42}$ of the converter $\mathrm{CON} 1$ which per pair are pulsed simultaneously. The pulses are the result from the comparison between a sinusoidal waveform $\left(\mathrm{U}_{\mathrm{st}}\right)$ with $0^{\circ}$ degree phase shifting and two triangular waveforms Utri $\left(0^{\circ}\right)$, Utri $\left(180^{\circ}\right)$ with $0^{\circ}$ and $180^{\circ}$ degree phase shifting respectively. The switching states are shown in table III.

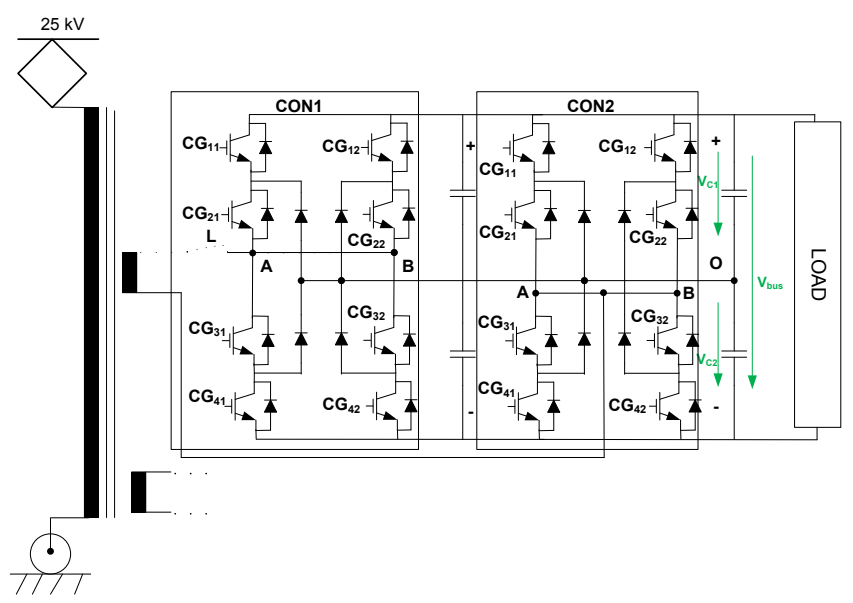

Fig. 5. H-NPC converter with parallel elements. 
TABle III-SWitching STATES OF CON1 CONVERTER

\begin{tabular}{|c|c|c|c|c|}
\hline & $\begin{array}{c}\text { Ust }> \\
\text { Utri }\left(0^{\circ}\right) \\
\text { and } \\
\begin{array}{c}\text { Ust }> \\
\text { Utri }\left(180^{\circ}\right)\end{array}\end{array}$ & $\begin{array}{c}\text { Ust }> \\
\text { Utri }\left(0^{\circ}\right) \\
\text { and } \\
\text { Ust }< \\
\text { Utri }\left(180^{\circ}\right)\end{array}$ & $\begin{array}{c}\text { Ust }< \\
\text { Utri }\left(0^{\circ}\right) \\
\text { and } \\
\text { Ust }> \\
\text { Utri }\left(180^{\circ}\right)\end{array}$ & $\begin{array}{c}\text { Ust }< \\
\text { Utri }\left(0^{\circ}\right) \\
\text { and } \\
\text { Ust }< \\
\text { Utri }\left(180^{\circ}\right)\end{array}$ \\
\hline $\begin{array}{c}\text { CG11\& } \\
\text { CG12 }\end{array}$ & On & Off & Off & Off \\
\hline $\begin{array}{c}\text { CG21\& } \\
\text { CG22 }\end{array}$ & On & On & On & Off \\
\hline $\begin{array}{c}\text { CG31\& } \\
\text { CG32 }\end{array}$ & Off & On & On & On \\
\hline $\begin{array}{c}\text { CG41\& } \\
\text { CG42 }\end{array}$ & Off & Off & Off & On \\
\hline $\mathrm{V}_{\mathrm{AO}}$ & $+\mathrm{V}_{\text {Bus }}$ & 0 & 0 & $-\mathrm{V}_{\text {Bus }}$ \\
\hline
\end{tabular}

The second control signal for the semiconductor elements $\mathrm{CG}_{11}, \mathrm{CG}_{12}, \mathrm{CG}_{21}, \mathrm{CG}_{22}, \mathrm{CG}_{31}, \mathrm{CG}_{32}, \mathrm{CG}_{41}, \mathrm{CG}_{42}$ of the converter $\mathrm{CON} 2$ which are also pulsed simultaneously per pair. For this converter the pulses are the result from the comparison between a sinusoidal waveform $\left(\mathrm{U}_{\mathrm{st}}\right)$ with $90^{\circ}$ degree phase shifting and two triangular waveforms Utri $\left(90^{\circ}\right)$, Utri $\left(270^{\circ}\right)$ with $90^{\circ}$ and $270^{\circ}$ degree phase shifting respectively. The switching states are shown in table IV.

TABLE IV-SWITCHING STATES OF CON2 CONVERTER

\begin{tabular}{|c|c|c|c|c|}
\hline & $\begin{array}{c}\text { Ust }> \\
\text { Utri }\left(90^{\circ}\right) \\
\text { and } \\
\begin{array}{c}\text { Ust }> \\
\text { Utri }\left(270^{\circ}\right)\end{array}\end{array}$ & $\begin{array}{c}\text { Ust }> \\
\text { Utri }\left(90^{\circ}\right) \\
\text { and } \\
\text { Ust }< \\
\text { Utri }\left(270^{\circ}\right)\end{array}$ & $\begin{array}{c}\text { Ust }< \\
\text { Utri }\left(90^{\circ}\right) \\
\text { and } \\
\text { Ust }> \\
\text { Utri }\left(270^{\circ}\right)\end{array}$ & $\begin{array}{c}\text { Ust }< \\
\text { Utri }\left(90^{\circ}\right) \\
\text { and } \\
\text { Ust }< \\
\text { Utri }\left(270^{\circ}\right)\end{array}$ \\
\hline $\begin{array}{c}\text { CG11\& } \\
\text { CG12 }\end{array}$ & On & Off & Off & Off \\
\hline $\begin{array}{c}\text { CG21\& } \\
\text { CG22 }\end{array}$ & On & On & On & Off \\
\hline $\begin{array}{c}\text { CG31\& } \\
\text { CG32 }\end{array}$ & Off & On & On & On \\
\hline $\begin{array}{c}\text { CG41\& } \\
\text { CG42 }\end{array}$ & Off & Off & Off & On \\
\hline $\mathrm{V}_{\text {BO }}$ & $-\mathrm{V}_{\text {Bus }}$ & 0 & 0 & $+\mathrm{V}_{\text {Bus }}$ \\
\hline
\end{tabular}

In practice, the single-phase sinusoidal grid voltage of $25 \mathrm{kV} \mathrm{AC}, 50 \mathrm{~Hz}$, transformed (degraded) to 510 Volts AC, $50 \mathrm{~Hz}$. Here we should mention that we have set the input inductor $20 \mathrm{mH}$, so the output voltage varying close to 900 Volts, which is the desired value. The three level H-bridge converter is connected at the output of the transformer. Figure 6 depicts the voltage of transformer's secondary winding, the sinusoidal control waveform and the triangular control waveforms for leg A. Also fig. 6 depicts the sinusoidal control waveform, the triangular control waveforms for leg $\mathrm{B}$, and the rectified $\mathrm{DC}$ voltage $\left(\mathrm{V}_{\text {bus }}\right)$ in the DC bus of the converter. The DC bus voltage is approximately 920 Volts.

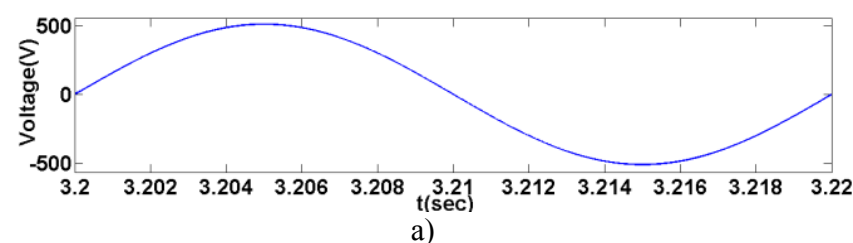

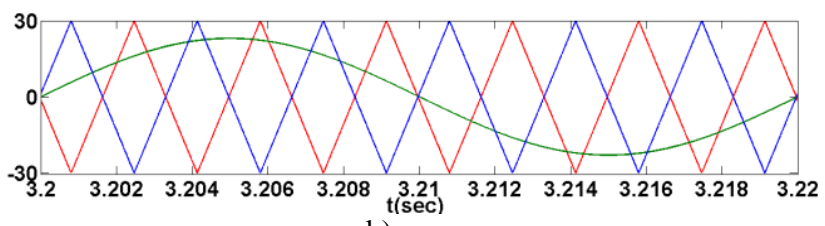

b)

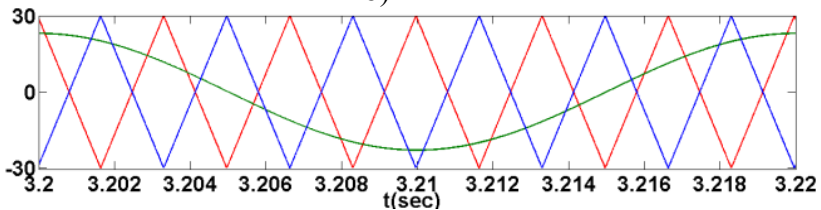

c)

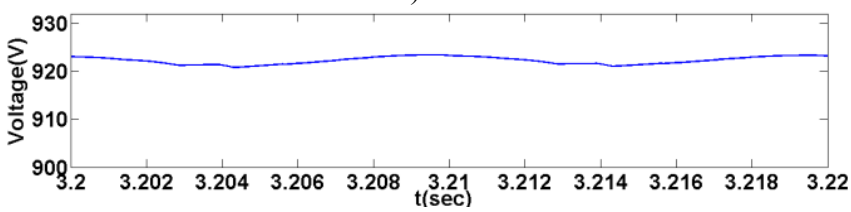

d)

Fig. 6. a) Voltage of transformer's secondary winding,

b) Control signal for converter $\mathrm{CON} 1$,

c) Control signal for converter CON2,

d) DC bus voltage.

As shown from fig. 6 the ripple of DC bus voltage is very small, approximately to $0.3 \%$ (from 921 until 924 volts). Each converter of the two above converters produces a three level line to neutral point voltage (neutral point of the DC bus), as shown in figure below. There is a phase shifting between the voltage waveforms of the two legs, this occurs because we want to create in the secondary winding of the transformer a five level voltage.

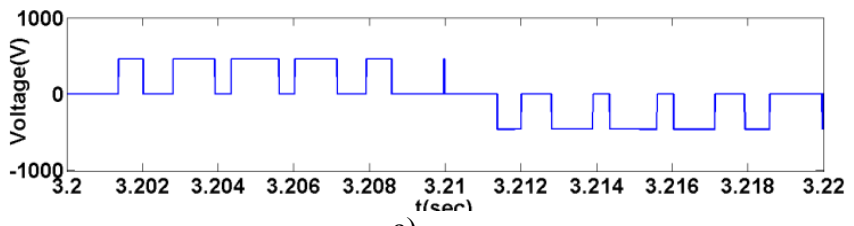

a)

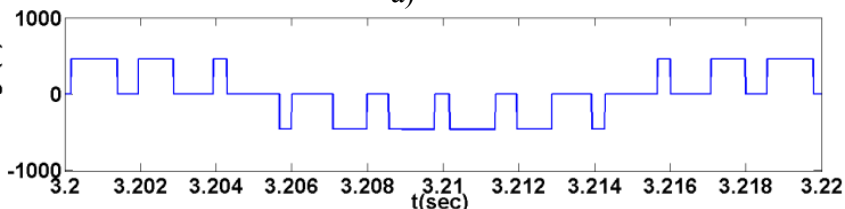

b)

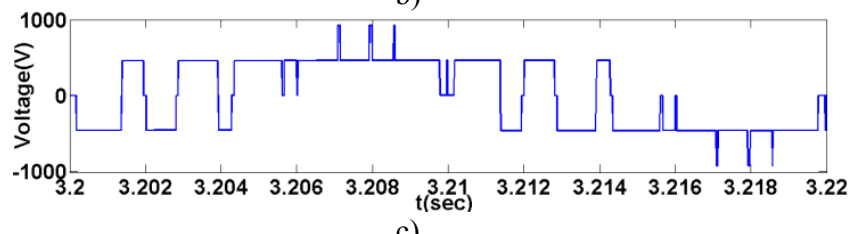

c)

Fig. 7. a) Line to neutral point voltage waveform for CON1, b) Line to neutral point voltage waveform for CON2, c) Line to line voltage waveform.

Figure 8 shows the input current of the topology and the current waveform of the primary winding of the transformer.

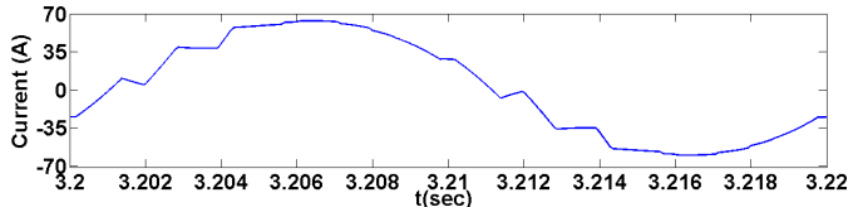

a) 


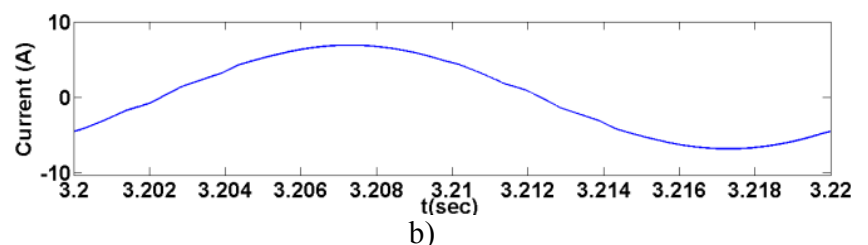

Fig. 8. a) Input current of the converter,

b) Current waveform of the primary winding of the transformer

The total harmonic distortion of the input current of the converter is: $\mathrm{THD}_{\mathrm{i}} \approx 7.47 \%$

The total harmonic distortion of the current in the primary winding of the transformer is: $\mathrm{THD}_{\mathrm{iP}} \approx 1.37 \%$

The phase shifting between transformer's secondary winding current and secondary winding voltage is $18^{\circ}$ degree. Therefore the power factor is: $\cos \varphi \approx 0.95$

\section{Two H-NPC converter parallel connected}

In this section, the two-parallel-connected H-NPC topology is investigated. Figure 9 depicts this topology connected to the grid via a transformer. The inductor in front of each of the two converters is $20 \mathrm{mH}$, in order to obtain the desired voltage at the DC side of the converter (DC $\mathrm{DCus}_{\text {) }}$.

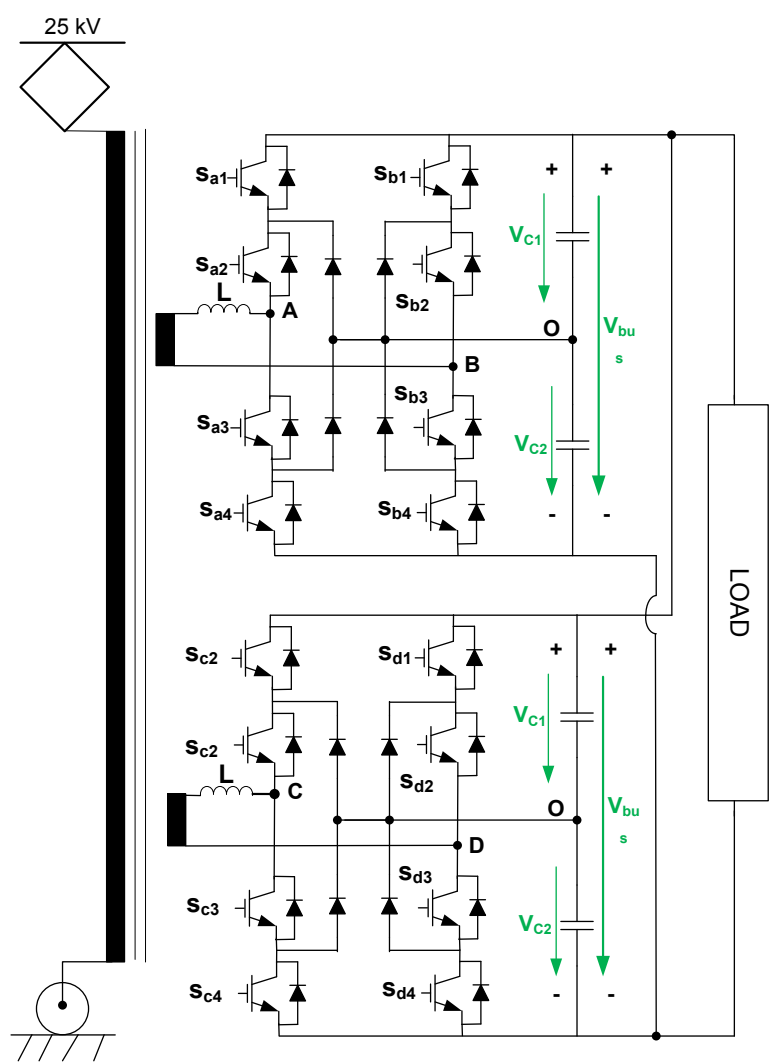

Fig. 9. Two H-NPC converters connected in parallel.

In this case the control strategy is similar with the control strategy of the H-NPC in section II. We have four different control signals, one for each leg (branch) of each converter. According to the tables I and II the pulses to the semiconductor elements are generated only if instead of $\mathrm{U}_{\mathrm{st}}$ and $\mathrm{U}_{\text {tri }}$ we place the appropriate control signals. To do this we need to consult the following table which summarizes the control signals which are compared and generate the final gating signals.

TABLE V-SWitching StATES OF CON2 CONVERTER

\begin{tabular}{|c|c|c|c|c|}
\hline & & Ust & Utri & Utri \\
\hline \multirow{2}{*}{ Upper } & Leg A & 0 & 0 & 180 \\
\cline { 2 - 5 } Converter & Leg B & 90 & 90 & 270 \\
\hline Lower & Leg C & 0 & 180 & 0 \\
\cline { 2 - 5 } Converter & Leg D & 90 & 270 & 90 \\
\hline
\end{tabular}

Assuming as the reference signal $\left(\mathrm{U}_{\mathrm{st}}\right)$ a sinusoidal signal with phase shifting $0^{\circ}$ compared to the input voltage $(510$ Volts). This reference signal will be indicated to leg A of the upper converter. The phase shifting that the other control signals should have to implement the logic of tables I and II are summarized in table V.

Figure 10 depicts the voltage of transformer's secondary winding which considered as a reference voltage, the sinusoidal control waveform for each leg according to the table $\mathrm{V}$ and the corresponding triangular control waveforms.

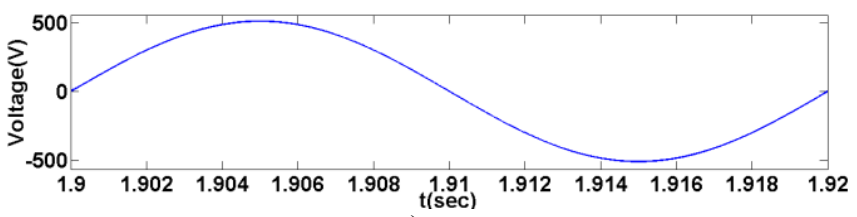

a)

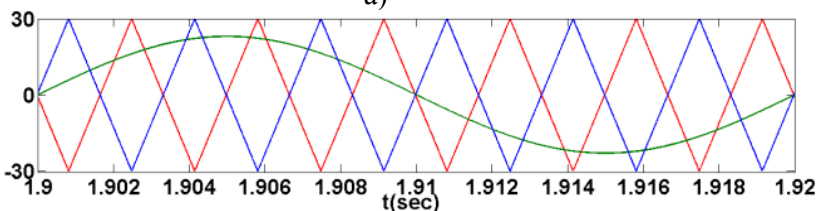

b)

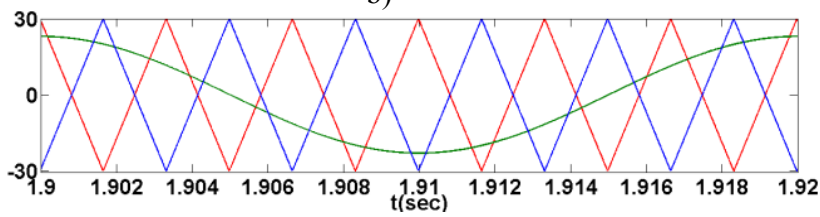

c)

Fig. 10. a) Input voltage $510 \mathrm{~V}$,

b) Control signal for leg a and leg c,

c) Control signal for leg $b$ and leg $d$

After the implementation of the control strategy and the generation of pulses at the appropriate time for each semiconductor element arises the DC bus voltage from the parallel converters. This voltage is between $880-900$ Volts, so we have a ripple factor nearly to $2.2 \%$.

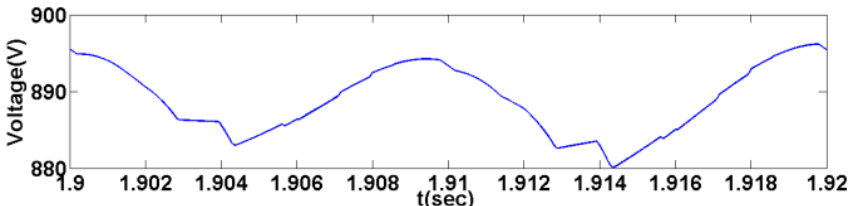

Fig .11. DC bus voltage.

Figures 12 and 13 show the voltages in the $\mathrm{AC}$ side of the converters. 


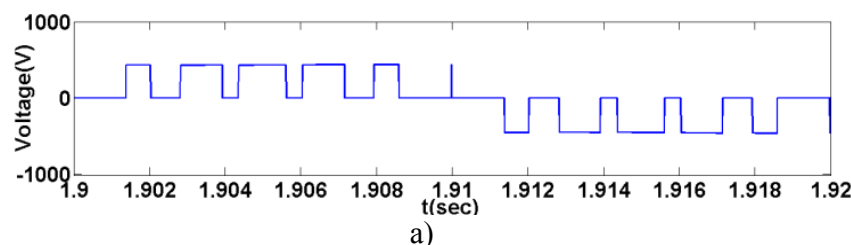

a)

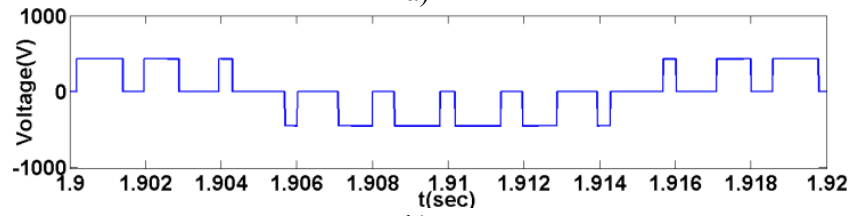

b)

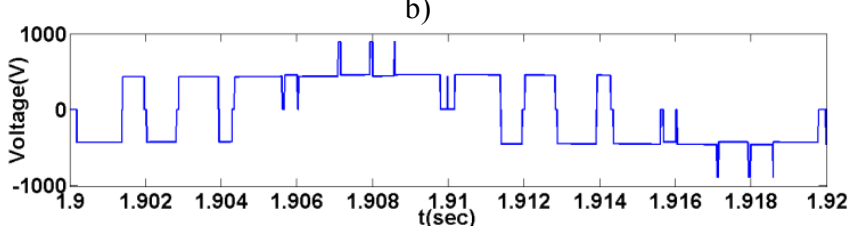

c)

Fig. 12. a) Line to neutral point voltage waveform $\mathrm{V}_{\mathrm{AO}}$,

b) Line to neutral point voltage waveform $\mathrm{V}_{\mathrm{BO}}$,

c) Line to line voltage waveform for the upper converter $\mathrm{V}_{\mathrm{AB}}$.

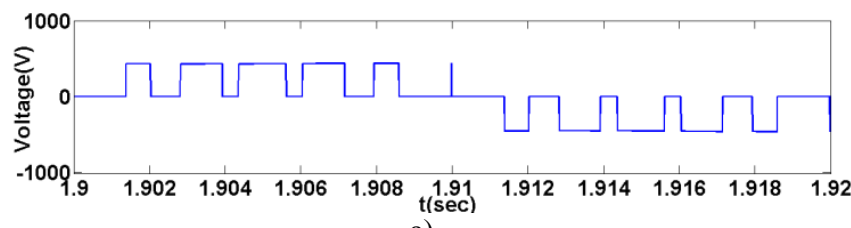

a)

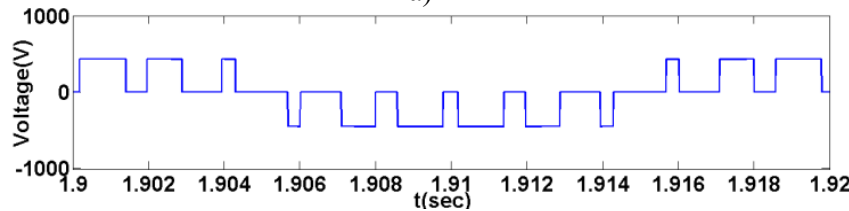

b)

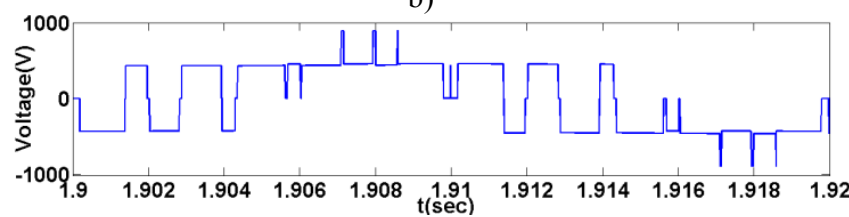

c)

Fig. 13. a) Line to neutral point voltage waveform $V_{C O}$,

b) Line to neutral point voltage waveform $V_{D O}$,

c) Line to line voltage waveform for the lower converter $\mathrm{V}_{\mathrm{CD}}$.

For this topology the current waveforms of the primary and the secondary winding of the transformer are shown in the figure below:

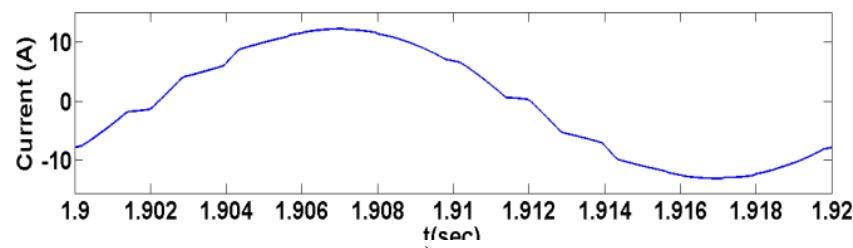

a)

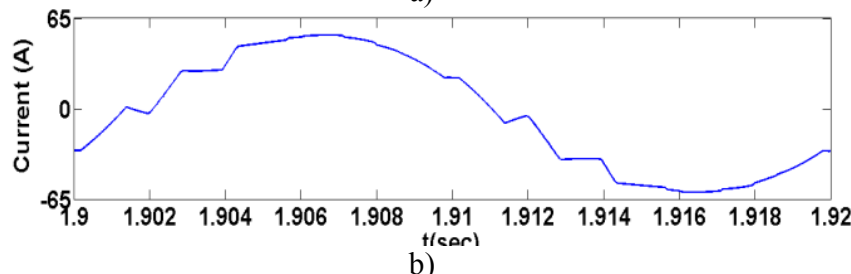

b)

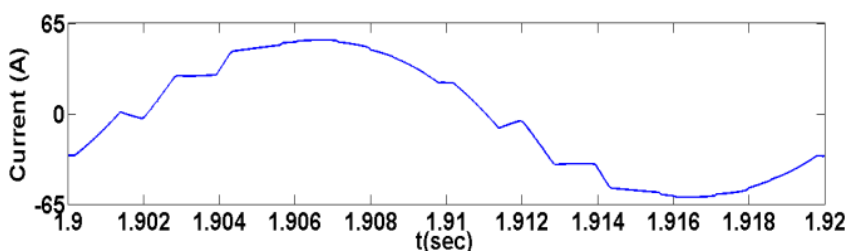

c)

Fig. 14. a) Primary winding current, b) Input current for upper converter,

c) Input current for bottom converter.

The total harmonic distortion of input current for the upper and the bottom converter is: $\mathrm{THD}_{\mathrm{i} 1}=\mathrm{THD}_{\mathrm{i} 2} \approx 7.28$ $\%$

The total harmonic distortion of the current in the primary winding of the transformer is: $\mathrm{THD}_{\mathrm{iP}} \approx 4.1 \%$

The phase shifting between transformer's secondary winding current and secondary winding voltage for the upper and the bottom converter is $36^{\circ}$ degree. Since the power factor is: $\cos \varphi \approx 0.81$

\section{Comparison between H-NPC converter, H-NPC converter with parallel elements and two H-NPC converter parallel connected two H-NPC converter parallel connected}

Observing the data in the table below, we conclude that the first two converters (H-NPC and H-NPC with parallel elements - H-NPC P.E.) have almost identical behavior, with a minimal difference in the ripple factor. The third converter (two parallel connected H-NPC - 2//H-NPC P.C.) with $7 \mathrm{mH}$ inductor, has the highest ripple factor, the highest $\mathrm{THD}_{\text {ip }}$ factor and the smallest power factor compared with the other two converters. From the other hand, the range of the input current, both for the upper and the bottom converter is much larger than the other two topologies. This fact contributes to the ability of this topology for greater power transfer.

TABLE VI-COMPARISON BETWEEN H-NPC, H-NPC P.E., AND 2// H-NPC P.C.

\begin{tabular}{|c|c|c|c|}
\hline & H-NPC & $\begin{array}{c}\text { H-NPC } \\
\text { P.E. }\end{array}$ & $\begin{array}{c}2 / / \mathrm{H}-\mathrm{NPC} \\
\text { P.C. }\end{array}$ \\
\hline $\begin{array}{c}\text { Output } \\
\text { Voltage }\end{array}$ & $925 \div 930 \mathrm{~V}$ & $921 \div 924 \mathrm{~V}$ & $880 \div 900 \mathrm{~V}$ \\
\hline Ripple & $0.5 \%$ & $0.3 \%$ & $2.2 \%$ \\
\hline $\begin{array}{c}\text { Input } \\
\text { Current }\end{array}$ & $-60 \div 60 \mathrm{~A}$ & $-60 \div 60 \mathrm{~A}$ & $-60 \div 60 \mathrm{~A}$ \\
\hline $\begin{array}{c}\text { Input current } \\
\text { THD }\end{array}$ & $7.48 \%$ & $7.47 \%$ & $7.28 \%$ \\
\hline $\begin{array}{c}\text { Primary } \\
\text { winding } \\
\text { current } \\
\text { THD }\end{array}$ & $1.38 \%$ & $1.37 \%$ & $4.1 \%$ \\
\hline cos $\varphi$ & 0.95 & 0.95 & 0.81 \\
\hline
\end{tabular}




\section{Conclusion}

In this paper, has been analyzed and compared the operation and the efficiency of various three level H-NPC topologies. In the analysis procedure, taking into account the control strategy, which is applied in each converter, is demonstrated in each case that the control voltages $\mathrm{u}_{\mathrm{st}}$ and the triangular waveforms $u_{\text {tri }}$ should have specific phase angles to achieve optimal operation of the converters and the optimal result in the electrical quantities. The simulation's results show that in the first two topologies the power factor and the current distortion in the primary and the secondary transformer's winding is quite satisfactory and almost identical for the two topologies. While comparing the third topology with the other two topologies, the current of the primary winding of the transformer appears harmonics with higher amplitude. Based on the aforementioned results, the usage of the $\mathrm{H}$ NPC with parallel elements is preferable, because this topology can transfer greater power compared to the first topology as well as compared to the third topology which uses only one winding in the secondary side of the transformer.

\section{References}

[1] N. Mohan, T. Undeland, W. Robbins, "Power Electronics: Converters Applications and Design," Wiley Text Books, Third Edition, 2002, ISBN: 0471226939.

[2] A. Trzynadlowski "Introduction to Modern Power Electronics", Wiley- Interscience, First Edition, 1998, ISBN: 0471153036

[3] Limits for Harmonic Current Emissions (Equipment Input Current up to and Including 16 A per Phase), IEC 61000-3-2 International Standard, 2000.

[4] J. Arrillaga, N. Watson, "Power System Harmonics", John Wiley \& Sons Inc, Second Edition, 2003, ISBN: 0470851295 .
[5] H. Akagi, H. Fujita "New Power Line Conditioner for Harmonic Compensation in Power Systems", IEEE Transactions on Power Delivery, Vol. 10, No 3, pp. 1570 1575, Jul. 1995.

[6] G. Adamidis, G. Tsengenes and K. Kelesidis, "Three Phase Grid Connected Photovoltaic System with Active and Reactive Power Control Using "Instantaneous Reactive Power Theory" International Conference on Renewable Energies and Power Quality (ICREPQ'10), Granada (Spain), 23th to 25th March, 2010.

[7] B. Singh, B. N. Singh, A. Chandra, K. Al-Hadad, A. Pandey, D. Kothari "A Review of Single-Phase Improved Power Quality AC-DC Converters," IEEE Transactions on Industrial Electronics, Vol. 50, No5, pp. 962-981, Oct. 2003.

[8] Xiao-Ping Zhang, Christian Rehtanz, Bikash Pal, "Flexible AC Transmision Systems: Modelling and Control" Springer-Verlag 2006,ISBN-10 3-540-30606-4.

[9] T. Watanabe, "Trend of railway technologies and power semiconductor devices," in Proc. 11th Int. Symp. Power Semiconductor Devices ICs, 1999, pp. 11-18.

[10] J. A. Taufig, "Step response prediction for traction VSI drive with emphasis on signaling compatibility," in Proc. IEEE Power Eng. Soc. Conf., Apr. 1998, pp. 1271-275.

[11] Gary W. Chang, Hsin-Wei Lin, Shin-Kuan Chen, "Modeling Characteristics of Harmonic Currents Generated by High-Speed Railway Traction Drive Converters", IEEE Transactions on Power Delivery, Vol.19, No2, April 2004.

[12] Alfred Rufer, Nikolaus Schibli, Christophe Chabert, Claudio Zimmermann, "Configurable Front-End Converters for Multicurrent Locomotives Operated on 16 $2 / 3 \mathrm{~Hz} \mathrm{AC}$ and $3 \mathrm{kV}$ DC Systems", IEEE Transactions on Power Electronics, Vol.18, No.5, September 2003.

[13] I. Etxeberria-Otadui, A. Lopez-de-Heredia, J. San Sebastian, H. Gaztanaga, U. Viscarret, M. Caballero. "Analysis of an H-NPC topology for an AC Traction Front-End Converter", EPE-PEMC, 2008.

[14] K. Kakikawa, Propulsion Control Systems Design Section, "ATTIKO METRO DV Train CONVERTER/INVERTER SYSTEM AND EQUIPMENT”, July 2002. 